Asian Journal of Agricultural Science 10(1): 1-8, 2019

DOI:10.19026/ajas.10.5982

ISSN: 2041-3882; e-ISSN: 2041-3890

(C) 2019 Maxwell Scientific Publication Corp.

Submitted: July 5, 2018

Accepted: July 31, 2018

Published: February 15, 2019

\title{
Research Article Decentralisation by Devolution and Farmers' Access to Agricultural Extension Services in Dodoma, Tanzania
}

\author{
${ }^{1}$ Zacharia S. Masanyiwa, ${ }^{2}$ Samwel J. Mdachi, ${ }^{1}$ Baltazar M.L. Namwata and ${ }^{1}$ John G. Safari \\ ${ }^{1}$ Institute of Rural Development Planning, P.O. Box 138, \\ ${ }^{2}$ President's Office-Regional Administration and Local Government, P.O. Box 1923, Dodoma-Tanzania
}

\begin{abstract}
The aim of this study to investigate the impact of decentralisation by devolution on farmers' access to agricultural extension services in selected villages in Dodoma, Tanzania. The specific objectives of the study are (i) to examine the availability and distribution of agricultural extension staff at ward and village levels and (ii) to examine farmers' accessibility to agricultural extension services at the local level. Data for the study were collected from a sample of 273 farmers in three wards of Hombolo, Kikombo and Chigongwe, using questionnaire survey, semi-structured interviews, focus group discussions and documentary review. Data analysis techniques involved descriptive statistics, chi-square test and qualitative content analysis. The findings show that implementation of decentralisation has contributed to increased availability and distribution of agricultural extension staff at the ward and village levels. This has enhanced farmers' access to several agricultural extension services. Nevertheless, the number of extension staff is still far below to meet the needs of farmers, partly because Local Government Authorities do not have the discretion to recruit their staff which is still under the mandates of the Central Government. It is recommended that local government authorities should be given more authority and mandates to recruit extension staff according to their needs.
\end{abstract}

Keywords: Access, agricultural extension service, availability, decentralisation by devolution, local government authorities, small scale farmers

\section{INTRODUCTION}

The agricultural sector plays a central role in the economy of many developing countries. In Tanzania, the sector provides about $67 \%$ of employment, accounts for about $23 \%$ of GDP, $30 \%$ of exports and $65 \%$ of inputs to the industrial sector (URT (United Republic of Tanzania), 2016). Yet, the sector remains underdeveloped and vulnerable to the whims of nature. Over the past few years, the sector has recorded an annual growth rate of $3.4 \%$, which is far below the target of $7.6 \%$ by 2020 and $13.1 \%$ by 2025 (URT (United Republic of Tanzania), 2015). One of the critical challenges facing agriculture in Tanzania is low productivity of land, labour and other production inputs, which is to some extent attributed to weak agricultural extension service linkage to farmers (URT (United Republic of Tanzania), 2013). Indeed, the importance of agricultural extension services in rural development is widely acknowledged as one of the drivers and preconditions for improving agricultural production and productivity (Haug, 1999; Nambiro et al., 2005; World Bank, 2010a; b; Msuya and Wambura, 2016). Agricultural extension services enable producers to realise increased production and productivity through accessibility to information for marketing and other support services essential for agricultural development (URT (United Republic of Tanzania), 2013). They are important in imparting farmers with the right tools, knowledge and skills as well as ensuring that farmers adhere to good agricultural practices (URT (United Republic of Tanzania), 2013; Msuya and Wambura, 2016).

However, in most developing countries, public agricultural extension services have for decades been heavily criticized for being top down and unresponsive to farmers' needs (Haug, 1999, JICA, 2008). In Tanzania, the national agriculture policy identifies the key issues affecting effective delivery of extension services, including: the lack of strong researchextension-farmers linkage; weak supervision and insufficient manning levels; low participation of private sector in extension services delivery; lack of service delivery performance standard and regulations; poor living and working conditions; and insufficient knowledge regarding technological advancements and weak coordination of agricultural extension services (URT (United Republic of Tanzania), 2013). Another

Corresponding Author: Zacharia S. Masanyiwa, Institute of Rural Development Planning, P.O. Box 138, Dodoma-Tanzania

This work is licensed under a Creative Commons Attribution 4.0 International License (URL: http://creativecommons.org/licenses/by/4.0/). 
major weakness which has been cited over time is the poor institutional, administrative and organizational structure within which extension services are provided to farmers. The bureaucratic organization of extension system has tended to contradict its very mission of working closely with farmers and with other service agencies to stimulate agricultural modernization (Matee, 1994; Rutatora and Mattee, 2001).

To ensure the performance of the agricultural sector, it is important that agricultural extension services in Tanzania are provided in the right frequency and time (Rutatora and Matee, 2001). Since the adoption of decentralisation by devolution (D by D) policy in 1998, agricultural extension services in Tanzania have been vested into Local Government Authorities (LGAs) to ensure effective participation of beneficiaries and motivate private sector involvement in service delivery (URT (United Republic of Tanzania), 1998; Daniel, 2013). This was done to give more autonomy and power to LGAs to decide and plan development activities on their own without interference from the central government. The main idea behind decentralization was to facilitate access to various services including bringing agricultural extension services closer to people. Within this framework, the role of the central government was defined as to formulate policy, give support and to monitor implementation of development projects (Daniel, 2013). The essence of decentralisation was to improve efficiency of extension service delivery to local communities (Msuya and Wambura, 2016).

Whether implementation of $\mathrm{D}$ by $\mathrm{D}$ has resulted in farmers' improved access to extension services is a question that warrants investigation. This question is crucial because the empirical evidence on the expected impact of decentralization on service delivery, for example, on primary healthcare and water supply services shows mixed results (Masanyiwa et al., 2015a; b). Despite the many studies that have focused on the performance of and access to agricultural extension services in Tanzania (e.g., Rutatora and Mattee, 2001; Msuya and Wambura, 2016), the impact of D by D on improving access to such services has, however, not been clearly documented in the academic literature. This study aims to contribute to this discussion by investigating the impact of $\mathrm{D}$ by $\mathrm{D}$ on improving farmers' access to agricultural extension services in rural Tanzania based on empirical findings obtained from selected villages in Dodoma Municipality. The specific objectives of the study are twofold:

- To examine the availability and distribution of agricultural extension staff at ward and village levels

- To examine farmers' accessibility to agricultural extension services at the local level.
The remainder of the study is organised as follows: The next section positions the study into the theory and context of decentralisation of agricultural extension reforms in Tanzania. Then, a description of the study area and methodology used in this study is presented, including the design, sample size, data types, sources and collection methods and how data were analysed. In what follows, the results of the study are presented and discussed, focusing on availability and distribution of extension officers and farmers' accessibility to extension services. In the last part of the study, we draw the key conclusions and recommendations emerging from the study.

\section{THEORY AND CONTEXT OF DECENTRALISATION OF AGRICULTURAL EXTENSION SERVICES}

Decentralisation is not a new phenomenon and has over the past four decades occupied central position in development policy and discourse. Most countries worldwide have attempted decentralisation of the fiscal, political and administrative responsibilities from central governments to lower level governments, albeit for different reasons (World Bank, 2004; 2008). Defined as the transfer of power and responsibility to plan, make decisions and manage public functions from a higher level of government to a lower one (Conyers, 1990), decentralisation has coincided with the global paradigm shift in development thinking and practice, from monocentric governance (where the state is the centre of political power and authority) towards polycentric governance, an idea of multiple centres of power within a state (Termeer et al., 2010). In this, decentralisation is seen as an appropriate response to the problems of state failure that were characteristic of many developing countries in the 1970s and 1980s and led into decline of most state provided public services (Batley, 2004; World Bank, 2004, Mehrotra, 2006).

In many developing countries, the rationale for decentralisation centres on the need to establish working local governments which can deliver quality services to the people in, where local authorities are directly accountable to the local people (World Bank, 2004; 2008). The theory is that, in a decentralised system public services should be more responsive to local needs because citizens can directly or indirectly influence decisions about resource allocation and service delivery. It is argued that decentralizing social delivery functions to local governments can result in better use of resources and deliver more appropriate services since decisions will reflect local needs and priorities (World Bank, 2004; 2008; Ribot et al., 2006; Andrews and de Vries, 2007). However, decentralization has not always been effective in improving service delivery by local governments, mainly because of lack of commensurate revenue 
source assignments and lack of necessary technical and administrative capacity on the part of local authorities (Ribot et al., 2006; Andrews and de Vries, 2007).

One such services that has been a good candidate of decentralisation is agricultural extension services. In the 1990s, agricultural extension services in many developing countries were attacked for being inefficient, irrelevant, ineffective and poorly targeted. There was increasing pressure to make extension services more effective, responsive to clients and less costly to government. Thus, the need for reform was obvious and national systems responded with three major strategies: decentralization, privatization and program revitalization (World Bank, 2000). As the World Bank (2000) puts it: "agricultural extension services are under increasing pressure to become more effective, more responsive to clients and less costly to government". Partly because of the geographic diversity and the need for organized farmer inputs, many countries opted to decentralise extension services down to the lowest administrative unit (World Bank, 2000; 2010a; Nambiro et al., 2005; Bashaasha et al., 2011). According to the World Bank (2010a), the main reason of decentralisation was to transform the topdown, technology-driven extension system into one that is more decentralized, farmer led and market driven. The argument is that a decentralised agricultural extension system creates avenues for small-scale farmers to be involved in setting extension priorities, as well as in assessing the performance of the field extension staff assigned to their specific service area.

Although decentralisation has been an important part of the development agenda in Tanzania for much of the post-independence period, recent reforms have been described as 'holistic' and 'far reaching' (URT (United Republic of Tanzania), 1998; 2008; Masanyiwa et al., 2013). The goal of the recent reforms was to restructure LGAs so that they can respond more effectively and efficiently to identified local priorities of service delivery (URT (United Republic of Tanzania), 1998; 2008; 2009). This entailed also changes in the delivery of agricultural extension services, which for many years were coordinated and financed by the public sector through the central government Ministry of Agriculture, Food Security and Cooperatives (MAFC). This arrangement was viewed as bureaucratic, ineffective and too far detached from farmers (Rutatora and Mattee, 2001), thus, was blamed for failing to serve its clients effectively (Msuya and Wambura, 2016).

Effective 1998, the government decided to transfer its entire extension field staff to LGAs in line with the D by D policy. With the Local Government Act No. 6 of 1999, LGAs are now the providers of agricultural extension services in their respective areas. They work closely with the MAFC and the President's Office Regional Administration and Local Government (PO-
RALG) in implementing relevant policies related to agricultural production (Rutatora and Matee, 2001). Structurally, the affairs of the LGA are managed by the Council Executive Director under the direction of the respective council consisting of councillors from each of the wards in the LGA. Agriculture is one of the departments within the local government structure responsible for agriculture, irrigation and cooperatives. In this case, the District Agriculture, Irrigation and Cooperatives Officer (DAICO) is answerable to the Council through the Executive Director on all administrative issues and technically to MAFC through the Regional Secretariat and PO-RALG. Decentralisation also recognizes the role of other nonstate actors including non-governmental organisations, community based organisations, farmers' associations, cooperative societies and farmers' networks, agribusinesses and religious organisations (Msuya and Wambura, 2016). So, to what extent have these decentralised arrangements resulted into improved farmers' access to agricultural extension services? We address this question after a description of the methodology.

\section{MATERIALS AND METHODS}

The research on which this study is based was carried in 2016 in selected wards of Hombolo, Kikombo and Chigongwe in the then Dodoma Municipality (now Dodoma City) in central Tanzania. The case wards were selected based on the fact that they are rural wards within the Municipality, thus, represent many rural and peri-urban areas in the country where agriculture is the main livelihood activity and where extension services are needed most.

A cross sectional research design, which involves asking questions to respondents at a single point in time was used in this study (Lynch, 2013). Primary and secondary data of qualitative and quantitative nature were collected using questionnaire survey, semistructured interviews, Focus Group Discussions (FGDs) and documentary review. A survey was conducted with a sample of 273 randomly selected farmers (obtained using Cochran's formula) and 20 extension staff using a structured questionnaire with both open and closed ended questions. The questionnaire was pre-tested prior to its administration to check its reliability and validity and make the necessary rectifications. The questionnaire aimed at collecting data on availability and distribution of agricultural extension staff and accessibility of farmers to extension services. Semistructured interviews were held with purposely selected key informants, including Ward Executive Officers (WEOs), Village Executive Officers (VEOs) and field agricultural extension staff in the study wards. These key informants were considered to have relevant information related to implementation of $\mathrm{D}$ by $\mathrm{D}$ policy 
and its impact on agricultural extension services in their areas.

In addition, two FGDs were held with farmers' groups. The first group involved male and female farmers who had no access to agricultural extension services while the second group consisted of farmers who had access to agricultural extension services. The FGDs were useful in obtaining different qualitative views and opinions on the impact of $\mathrm{D}$ by $\mathrm{D}$ on farmers' access to agricultural extension services in the study area. Overall, triangulation of data collection methods enhanced accuracy, authenticity, validity, reliability and credibility of the findings, because of the combined strength of each method, which also helped to counterbalance the weaknesses of using only one data collection method (Cohen, 2000). To determine whether there have been changes in availability, distribution and farmers access to agricultural extension services, the study also incorporated a longitudinal perspective by asking retrospective questions to farmers and key informants as part of the survey, interviews and FGDs.

Quantitative data collected through the questionnaire survey were processed using the Statistical Package for Social Sciences (SPSS) version 20 and analysed for descriptive statistics, including frequencies, percents and means and chi-square test to test for association among the variables. Qualitative content analysis was used to analyse qualitative data which involved reading through the field notes and transcripts to identify key themes and patterns relevant to the research concepts. The following section presents and discusses the findings, weaving together quantitative and qualitative data.

\section{RESULTS AND DISCUSSION}

Socio-demographic characteristics of farmers: The socio-demographic characteristics of farmers examined in this study included sex, education level, duration of stay in the village and occupation (Table 1). More than half (57\%) of the surveyed farmers were males whereas $43 \%$ were females. This could be partly due to the patriarchal system in the study area where most households are male headed, although women play an important role in agriculture as the main producers. Close to two thirds of the respondents (64\%) had primary education, another $20 \%$ had secondary education or above, but $16 \%$ had not received any formal education. A World Bank (2010b) study in Ethiopia revealed that better-educated farmers were somewhat more likely to receive farm or home visits by extension officers and a much greater proportion of literate than illiterate farmers attended extension community meetings and visited demonstration plots. Nevertheless, despite the low levels of education attainment, their wide experience in agricultural activities was considered crucial in providing relevant information on the issues investigated in this study.

Further, two thirds of the respondents (66\%) were between 36 and 45 years which is the most productive age group. Overall, $94 \%$ of the surveyed farmers had either stayed in their respective villages since birth (61\%) or for more than 10 years (33\%). These farmers were likely to have the relevant knowledge and experience on the various issues, including the changes in the availability and access to extension services in their areas. More than half of the respondents (51\%) practiced both farming and livestock keeping, over one third were engaged in farming only (35\%) and one in ten of the respondents was involved in livestock production only $(10 \%)$. The implication of these findings is that majority of the surveyed households were involved in agricultural related activities, which needed agricultural extension services of one type or another.

Availability and distribution of agricultural extension staff: In this study, availability and distribution of agricultural extension staff was assessed in terms of number of agricultural extension staff in the study wards and villages and education level of agricultural extension staff. It was found that before implementation of D by D policy in 2000, only about $4 \%$ and $46 \%$ of villages and wards, respectively, in Dodoma Municipality had agricultural extension staff. After implementation of $\mathrm{D}$ by $\mathrm{D}$, availability of extension staff in the villages and wards increased to about $7 \%$ and $73 \%$, respectively, in 2015 . There were 43 extension staff in the Municipality in 2015 compared to only 22 in 2000, indicating an increase of over $95 \%$ (Table 2). The observed increased number of extension staff across the villages and wards was mainly attributed to implementation of D by D.

Within the decentralised local government system, LGAs are responsible for identifying and planning to meet human resource needs of extension staff, staff confirmation, performance appraisals, some promotion decisions, staff development and transfers within LGAs. However, the available agricultural extension staff were still not enough to meet the demand of farmers. In Tanzania, the extension service policy aims at one agricultural extension officer per village and ward and there were 9,139 spread over 168 LGAs in 2014 (URT (United Republic of Tanzania), 2015). This arrangement has, however, been a subject of discussion and critique because villages and wards vary in size and population. In some villages and wards, one extension staff may sometimes not be enough to meet the extension needs and demands of farmers. This issue also featured in our FGDs and key informant interviews where respondents said that extension staff were inadequate and sometimes not available at all. A similar finding was reported by Msuya and Wambura (2016) 
Asian J. Agric. Sci., 10(1): 1-8, 2019

Table 1: Characteristics of respondents by sex $(\mathrm{n}=273)$

\begin{tabular}{lllll}
\hline Variable & Responses & Male & Female & Total \\
\hline Age (years) & $18-35$ & $42(27.1)$ & $30(25.4)$ & $72(26.4)$ \\
& $36-45$ & $97(62.6)$ & $82(69.5)$ & $179(65.6)$ \\
& $46-60$ & $14(9.0)$ & $4(3.4)$ & $18(6.6)$ \\
Education level & Above 60 & $2(1.3)$ & $2(1.7)$ & $4(1.5)$ \\
& No formal education & $25(16.1)$ & $18(15.3)$ & $43(15.8)$ \\
& Primary education & $99(63.9)$ & $76(64.4)$ & $175(64.1)$ \\
Duration of stay in the village & Secondary education & $29(18.7)$ & $24(20.3)$ & $53(19.4)$ \\
& Higher education & $2(1.3)$ & $0(0.0)$ & $2(0.7)$ \\
Occupation & Since birth & $98(63.2)$ & $68(57.6)$ & $166(60.8)$ \\
& Less than 10 years & $12(7.7)$ & $5(4.2)$ & $17(6.2)$ \\
& More than 10 years & $45(29.0)$ & $45(38.1)$ & $90(33.0)$ \\
& Farming only & $55(35.5)$ & $40(33.9)$ & $95(34.8)$ \\
& Livestock keeping & $19(12.3)$ & $8(6.8)$ & $27(9.9)$ \\
\hline
\end{tabular}

Figures in brackets are percents

Table 2: Availability of extension staff in wards and villages in 2000 and 2015

\begin{tabular}{lll}
\hline Administrative unit & 2000 & 2015 \\
\hline Number of wards & 37 & 41 \\
Number of wards with extension officers & $17(45.9)$ & $30(73.1)$ \\
Number of villages/mitaa & \\
$\begin{array}{l}\text { Number of villages/mitaa } \text { with extension } \\
\text { officers }\end{array}$ & $5(3.9)$ & 188 \\
\hline
\end{tabular}

Figures in brackets are percents

who found inadequate extension services in Morogoro and Dodoma regions, which were attributed to lack or low number of extension staff. Further, within the current decentralisation framework, LGAs do not have the discretion to recruit their staff as such mandates are still under the mandates of central government, through President's Office - Public Service Management and Good Governance.

The findings show that over half of agricultural extension staff (55\%) had a college diploma and another $45 \%$ had college certificate in an agricultural related discipline (general agriculture, horticulture, animal husbandry or animal health). Extension staff with college diplomas were mostly deployed to serve at the ward level whereas those with college certificates were placed at village level. In the context of decentralised local government system in Tanzania, the ward is technically an administrative unit responsible for coordinating development activities, planning and linking plans with council level (Venugopal and Yilmaz, 2010; Masanyiwa et al., 2013). This means that extension staff at the ward level are mostly involved in coordination issues and connecting the villages with council headquarters. Thus, they are less likely to have direct contacts with farmers at villages, kitongojii $i^{i i}$ and household levels.

Implicitly, these findings show that the higher the level of education an extension staff has, the higher the likelihood of being detached from direct interaction with farmers in the field. In other words, the current decentralised arrangement of extension services appears to be hierarchical with less consideration being given to the lower village levels where extension services are needed most. This means that decentralisation of extension services has not necessarily made the services less top-down, a finding which was also observed by the World Bank (2010b) in Ethiopia. This could also mean that extension staff at the lower levels, particularly the village level need further training to enhance their knowledge and capacity in handling various extension issues to provide technical support in agricultural activities.

Farmers access to extension services: In this study, access to extension services was measured in terms of proportion of farmers reporting to have had been visited by agricultural extension services; type of extension services available to farmers, their frequency and where farmers obtained these services. The survey findings in Table 3 show that just over one quarter of the farmers (26\%) reported that had been visited by an extension staff in 2000, but this proportion had significantly increased to over $80 \%$ in 2015. More than three quarters of the farmers (76\%) reported to have been trained on the use of improved inputs and farming technologies in 2015, which had almost tripled from only $26 \%$ in 2000 . Similarly, an overwhelming majority of farmers (95\%) reported that were using modern farming implements for land preparation in 2015 compared to $26 \%$ in 2000. Elsewhere, the World Bank (2010b) reported that only $24 \%$ of the farmers in Karnataka (India) and 54\% in Tigray-D (Ethiopia) had visits by extension agents even after implementing decentralisation of the agricultural extension system.

Comparatively, a higher proportion of female farmers reported to have had been visited by extension staff, trained on use of improved inputs and technologies and used modern farming implements than their male counterparts. This reflects the important role played by women in agriculture as farmers, agricultural labourers and livestock rearers (World Bank, 2010b). Whereas agricultural extension services in the past have been blamed for being geared towards male farmers and 
Asian J. Agric. Sci., 10(1): 1-8, 2019

Table 3: Farmers access to extension services in 2000 and $2015(n=273)$

\begin{tabular}{lllllll} 
& 2000 & & & 2015 & & \\
Service & - & & & \\
- & Male & Female & Total & Male & Female & Total \\
\hline Visited by extension staff & $26(16.8)$ & $44(37.3)$ & $70(25.6)$ & $110(71.0)$ & $109(92.4)$ & $219(80.2)$ \\
Trained on improved inputs and technologies & $30(19.4)$ & $42(35.6)$ & $72(26.4)$ & $107(69.0)$ & $100(84.7)$ & $207(75.8)$ \\
Used modern implements for land preparation & $31(20.0)$ & $41(34.7)$ & $72(26.4)$ & $143(92.3)$ & $115(97.5)$ & $258(94.5)$ \\
\hline Fig
\end{tabular}

Figures in brackets are percents

Table 4: Source of extension services $(n=258)$

\begin{tabular}{llll}
\hline Service & Male & Female & Total \\
\hline $\begin{array}{l}\text { Government extension } \\
\text { staff }\end{array}$ & $75(52.4)$ & $67(58.3)$ & $142(55.0)$ \\
Private extension staff & $3(2.1)$ & $0(0.0)$ & $3(1.2)$ \\
NGO extension staff & $3(2.1)$ & $0(0.0)$ & $3(1.2)$ \\
$\begin{array}{l}\text { Progressive farmers } \\
\text { (farmer to farmer) }\end{array}$ & $62(43.4)$ & $48(41.7)$ & $110(42.6)$ \\
\hline
\end{tabular}

Figures in brackets are percents

viewed women as less important (Haug, 1999), these findings suggest that extension services provided in the study area within the decentralisation framework were gender sensitive (World Bank, 2010b). It was revealed from the key informant interviews and FGDs that as part of implementation of $\mathrm{D}$ by $\mathrm{D}$, the LGA also established Ward Agriculture Resource Centres that enabled farmers to access extension services within their vicinity. In turn, this has contributed to improved accessibility of farmers to agricultural extension services. In Uganda, Bashaasha et al. (2011) found that decentralisation was perceived to have enhanced participation of local communities in planning and implementing agricultural extension programs.

The findings in Table 4 further show that more than half of the farmers obtained information on the use of improved farming techniques mostly from government agricultural extension officers located in their respective wards and villages (55\%) and another substantial proportion from progressive farmers (43\%). Very few farmers reported that had access to private and NGO extension agents (2\%), implying that most farmers depended on extension services provided by the government through local governments. This reflects earlier observations that agricultural extension services in Tanzania are mainly provided and financed by the public, although NGOs and farmer-led initiatives have, over time, supplemented extension service delivery (Rutatora and Mattee, 2001; Msuya and Wambura, 2016). In fact, public extension service is largely provided for free, thus, mostly accessible to smallholder farmers whereas private extension service is in most cases charged and accessible to middle and large-scale farmers (Msuya and Wambura, 2016). In Kenya, Nambiro et al. (2005) found that government extension agents were highly regarded by farmers and more likely to be sought out for advice and that such advice, once given, was relatively more likely to be operationalized by farmers.

Almost all farmers in the surveyed households had access to at least one type of extension service. A large majority reported that were receiving advice on use of improved seeds and fungicides (81\% each), with significantly higher proportion of female than male farmers (Table 5). Technical advice on the use of farm implements and crop pesticides were also highly accessible as reported by $78 \%$ and $72 \%$ of the respondents, respectively, again female farmers indicating significantly $(p<0.05)$ higher access compared to male farmers. Over two thirds of farmers had access to livestock treatment (69\%) and dipping services (68\%) and another $63 \%$ received advice on the use of improved livestock production methods. In this regard, however, no significant difference was observed between male and female farmers. Another half of the households indicated having access to artificial insemination and livestock vaccination services (51\%, each). This shows that majority of the respondents had access to most of the extension services they needed and that gender of the household head was an important determinant in accessing extension services. The findings contradict those by Nambiro et al. (2005) in Kenya who found a male bias in accessing extension services.

On average, farmers in the study wards were receiving about eight out of the eleven services considered in this study (eight for female farmers and seven for male farmers). Over two thirds of the farmers reported to be receiving seven or more services $(67 \%$ males and $70 \%$ females), only about a quarter (24\%) had access to $4-6$ services (21\% males vs $24 \%$ females) and another $5 \%$ received between 1 and 3 services. In India, farmers reported an average of 3.5 contacts per year with extension agents (World Bank, 2010b). Thus, our findings imply high rate of contacts between extension staff and farmers, which in part could be a result of the decentralised extension system.

The frequency of farmers' access to different extension services was measured using a five-point Likert scale questions ranging from 'not at all' to 'very often'. The results show that visits to farmers by extension staff and advice on improved seeds ranked first with mean scores of 3.4 and 3.3, respectively (Table 6), which could be interpreted that farmers 'often' received extension services. Advice on use of pesticides (mean score, 3.0), fungicides (mean score, 2.8), farm implements (mean score, 2.7) and farming techniques (mean score, 2.6) were ranked as being 'rarely' accessible. Other services had mean scores of close to 2, which could be interpreted as 'sometimes' accessible. Amongst others, implementation of $\mathrm{D}$ by $\mathrm{D}$ 
Asian J. Agric. Sci., 10(1): 1-8, 2019

Table 5: Farmers' perceptions on access to extension services by household headship ( $\mathrm{n}=273$ )

\begin{tabular}{|c|c|c|c|c|c|}
\hline Service & Male & Female & Total & $X^{2}$-value & $p$ \\
\hline Advice on use of improved seeds & $112(72.3)$ & $109(92.4)$ & $221(81.0)$ & 17.58 & 0.000 \\
\hline Advice on use of pesticides & $100(64.5)$ & $96(81.4)$ & 196(71.8) & 9.38 & 0.002 \\
\hline Advice on use of fungicides & $120(77.4)$ & $102(86.4)$ & $222(81.3)$ & 3.59 & 0.058 \\
\hline Advice on use of implements & $115(74.2)$ & $99(83.9)$ & $214(78.4)$ & 3.73 & 0.054 \\
\hline Advice on use of improved farming techniques & $92(59.4)$ & $81(68.6)$ & 173(63.4) & 2.49 & 0.115 \\
\hline Advice on use of improved livestock production methods & 99(63.9) & 73(61.9) & 172(63.0) & 0.12 & 0.734 \\
\hline Artificial insemination services & $80(51.6)$ & $58(49.2)$ & $138(50.5)$ & 0.16 & 0.687 \\
\hline Livestock vaccination services & $82(52.9)$ & $58(49.2)$ & $140(51.3)$ & 0.38 & 0.539 \\
\hline Livestock dipping services & $101(65.2)$ & $84(71.2)$ & 185(67.8) & 1.11 & 0.291 \\
\hline Livestock treatment services & $100(64.5)$ & 87(73.7) & $187(68.5)$ & 2.64 & 0.105 \\
\hline
\end{tabular}

Figures in brackets are percents

Table 6: Frequency of farmers' accessibility to extension services per year by ward $(n=273)$

\begin{tabular}{|c|c|c|c|c|c|c|}
\hline Service & Not at all & Sometimes & Rarely & Often & $\begin{array}{l}\text { Very } \\
\text { often }\end{array}$ & Mean \\
\hline Visited by Agriculture extension officers & $37(13.6)$ & $47(17.2)$ & $12(4.4)$ & $115(42.1)$ & $62(22.7)$ & 3.4 \\
\hline $\begin{array}{l}\text { Support from agricultural extension officers in terms of improved } \\
\text { seeds }\end{array}$ & $40(14.7)$ & $66(24.2)$ & $8(2.9)$ & $99(36.3)$ & $60(22.0)$ & 3.3 \\
\hline $\begin{array}{l}\text { Support from agricultural extension officers in terms of } \\
\text { pesticides }\end{array}$ & $50(18.3)$ & $90(33.0)$ & $17(6.2)$ & $57(20.9)$ & $59(21.6)$ & 3.0 \\
\hline $\begin{array}{l}\text { Support from agricultural extension officers in terms of } \\
\text { fungicides }\end{array}$ & 63(23.1) & $86(31.5)$ & $14(5.1)$ & $52(19.0)$ & $58(21.2)$ & 2.8 \\
\hline $\begin{array}{l}\text { Support from agricultural extension officers in terms of } \\
\text { implements }\end{array}$ & $75(27.5)$ & $80(29.3)$ & 16(5.9) & 49(17.9) & 53(19.4) & 2.7 \\
\hline Training from extension workers on improved farming methods & $90(33.0)$ & $71(26.0)$ & 12(4.4) & $55(20.1)$ & $45(16.5)$ & 2.6 \\
\hline $\begin{array}{l}\text { Training from extension workers on improved livestock } \\
\text { production methods }\end{array}$ & 111(40.7) & $66(24.2)$ & 13(4.8) & $53(19.4)$ & $30(11.0)$ & 2.4 \\
\hline Livestock artificial insemination services & 108(39.6) & $75(27.5)$ & 27(9.9) & $33(12.1)$ & $30(11.0)$ & 2.3 \\
\hline Livestock vaccination services & 114(41.8) & $75(27.5)$ & $8(2.9)$ & $50(18.3)$ & 26(9.5) & 2.3 \\
\hline Livestock dipping services & 98(35.9) & 84(30.8) & $6(2.2)$ & $52(19.0)$ & 33(12.1) & 2.4 \\
\hline Livestock treatment services & $97(35.5)$ & $86(31.5)$ & $13(4.8)$ & $45(16.5)$ & $32(11.7)$ & 2.4 \\
\hline
\end{tabular}

Figures in brackets are percents

promoted the increased number of ward agriculture resource centres and extension block grant component that is available for training of agriculture extension officers.

\section{CONCLUSION AND RECOMMENDATIONS}

This study has investigated the impact of $\mathrm{D}$ by $\mathrm{D}$ on farmers' access to agricultural extension services in selected rural wards and villages of Dodoma Municipality. One of the key conclusions emerging from the findings is that implementation of $\mathrm{D}$ by $\mathrm{D}$ has contributed to increased availability and distribution of agricultural extension staff across the wards and villages. Currently, there are more extension staff in wards and villages than were before implementation of the D by D policy. This has enhanced farmers' access to a number of agricultural extension services. Many farmers are now frequently being visited by agricultural extension staff. The farmers also receive support and training on several extension services. However, the number of extension staff is still far below the required level, partly because LGAs do not have the discretion to recruit their staff. It is recommended that the current policy for agricultural extension service provision should be reviewed because having one extension staff in each village does not necessarily meet the demand of farmers given the variations in geographical coverage and population size between villages.

\section{REFERENCES}

Andrews, C.W. and M.S. de Vries, 2007. High expectations, varying outcomes: Decentralization and participation in Brazil, Japan, Russia and Sweden. Int. Rev. Administ. Sci., 73(3): 424-451.

Bashaasha, B., M.N. Mangheni and E. Nkonya, 2011. Decentralization and Rural Service Delivery in Uganda. International Food Policy Research Institute (IFPRI). Development Strategy and Governance Division. IFPRI Discussion Paper 01063.

Batley, R., 2004. The politics of service delivery reform. Develop. Change, 35(1): 31-56.

Cohen, L., 2000. Research Methods in Education. Routledge Falmer, London.

Conyers, D., 1990. Decentralization and development planning. In: de Valk, P. and K.H. Wekwete, (Eds.): Decentralizing for participatory development? Comparing the Experiences of Zimbabwe and Other Anglophone Countries in Eastern and Southern Africa Aldershot, Avebury, pp: 15-33.

Daniel, E., 2013. Assessment of agricultural extension services in Tanzania. A Case Study of Kyela, Songea Rural and Morogoro Rural Districts. Internship Report in Plant Sciences. University of Wageningen, Wageningen, Netherlands.

Haug, R., 1999. Some leading issues in international agricultural extension, a literature review. J. Agri. Edu. Extens., 5(4): 263-274. 
JICA, 2008. Local Service Delivery, Decentralization and Governance. A comparative Study of Uganda, Kenya and Tanzania Education, Health and Agriculture Sectors. Research Group, Institute for International Cooperation (IFIC), Tokyo.

Lynch, S.M., 2013. Using statistics in social research. Princeton University, New Jersey.

Masanyiwa, Z.S., A. Niehof and C.J.A.M. Termeer, 2013. Institutional arrangements for decentralized water and health services delivery in rural Tanzania: Differences and constraints. Basic Res. J. Soc. Pol. Sci., 1(4): 77-88.

Masanyiwa, Z.S., A. Niehof and C.J. Termeer, 2015a. A gendered users' perspective on decentralized primary health services in Rural Tanzania. Int. J. Health Plann. Manage., 30(3): 285-306.

Masanyiwa, Z.S., A. Niehof and C.J. Termeer, 2015b. Users' perspectives on decentralized rural water services in rural Tanzania. Gender, Place Cult. J. Feminist Geograp., 22(7): 920-936.

Matee, A.Z., 1994. Reforming Tanzania's agricultural extension system: The challenges ahead. Afri. Stud. Monograp., 15(4): 177-188.

Mehrotra, S., 2006. Governance and basic social services: Ensuring accountability in service delivery through deep democratic decentralization. J. Int. Develop., 18(2): 263-283.

Msuya, C.P. and R.M. Wambura, 2016. Factors influencing extension service delivery in maize production by using agricultural innovation system in Morogoro and Dodoma Regions, Tanzania. South Afr. J. Agric. Ext., 44(2): 248-255.

Nambiro, E., J. Omiti and L. Mugunieri, 2005. Decentralization and Access to Agricultural Extension Services in Kenya. Strategies and Analysis for Growth and Access, (SAGA) a project of Cornell and Clark Atlanta Universities, funded by cooperative agreement \#HFM-A-00-010013200 with the United States Agency for Interna tional Development. SAGA Working Paper, October 2005.

Ribot, J.C., A. Agrawal and A.M. Larson, 2006. Recentralizing while decentralizing: How national governments re-appropriate forest resources. World Develop., 34(11): 1864-1886.

Rutatora, D.F. and A.Z. Mattee, 2001. Major agricultural extension providers in Tanzania. Afri. Stud. Monograp., 22(4):155-173.

Termeer, C.J.A.M., A. Dewulf and M. van Lieshout, 2010. Disentangling scale approaches in governance research: Comparing monocentric, multilevel and adaptive governance. Ecol. Soc., 15(4): 29.

URT (United Republic of Tanzania), 1998. Policy Paper on Local Government Reform. Local Government Reform Program. Ministry of Regional Administration and Local Government. Local Government Reform Programme, Dar es Salaam.
URT (United Republic of Tanzania), 2008. The Status of Implementation of Decentralisation by Devolution on Mainland Tanzania and the Way Forward. Paper Presented at the National Convention on Public Sector Reforms 17-18th June 2008, Ubungo Plaza, Dar es Salaam.

URT (United Republic of Tanzania), 2009. Local Government Reform Programme II (Decentralization by Devolution): Vision, Goals and Strategy July 2009-June 2014. Prime Minister's Office-Regional Administration and Local Government, Dodoma.

URT (United Republic of Tanzania), 2013. National Agricultural Policy. Ministry of Agriculture, Food Security and Cooperatives, Dar es Salaam.

URT (United Republic of Tanzania), 2015. Agricultural Sector Development Strategy II 2015/20162024/2025. Ministry of Agriculture, Food Security and Cooperatives, Dar es Salaam.

URT (United Republic of Tanzania), 2016. National Five-Year Development Plan 2016/2017-2020/21. Nurturing Industrialization for Economic Transformation and Human Development. Ministry of Finance and Planning, Dar es Salaam.

Venugopal, V. and S. Yilmaz, 2010. Decentralization in Tanzania: An assessment of local government discretion and accountability. Pub. Administ. Develop., 30(3): 215-231.

World Bank, 2000. Decentralizing Agricultural Extension: Lessons and Good Practice. Agricultural Knowledge and Information Systems (AKIS), The World Bank, Washington D.C.

World Bank, 2004. World Bank Development Report 2004: Making Services Better for Poor People. The World Bank, Washington, D.C.

World Bank, 2008. Decentralization in Client Countries. An Evaluation of World Bank Support, 1990-2000. World Bank Independent Evaluation Group, The World Bank, Washington, D.C.

World Bank, 2010a. Strengthening Agricultural Extension and Advisory Systems: Procedures for Assessing, Transforming and Evaluating Extension Systems. Agriculture and Rural Development Discussion Paper 45. The World Bank.

World Bank, 2010b. Gender and Governance in Rural Services: Insights from India, Ghana and Ethiopia. The International Food Policy Research Institute. The World Bank, Washington, D.C:

\section{End note:}

${ }^{\mathrm{i}}$ : The mtaa (plural mitaa) is the lowest unit of government in urban areas in Tanzania. Each urban ward is divided into mitaa or neighborhoods consisting of a number of households, which the urban council may determine.

ii : The kitongoji (plural vitongoji) is the lowest unit of government in rural areas in Tanzania. Each rural village is divided into kitongoji or neighborhoods consisting of a number of households, which the district council may determine. 